\title{
Novel Treatments and Technologies Applied to the Cure of Neuroblastoma
}

\author{
Irene Paraboschi ${ }^{1,2,3}{ }^{D}$, Laura Privitera ${ }^{1,3}$, Gabriela Kramer-Marek ${ }^{2}{ }^{(D}$, John Anderson ${ }^{3}$ (D) \\ and Stefano Giuliani $1,4, * \mathbb{D}$
}

1 Wellcome/EPSRC Centre for Interventional \& Surgical Sciences, University College London, London WC1E 6BT, UK; i.paraboschi@ucl.ac.uk (I.P.); Laura.Privitera@gosh.nhs.uk (L.P.)

2 Preclinical Molecular Imaging, Division of Radiotherapy and Imaging, The Institute of Cancer Research, London SM2 5NG, UK; Gabriela.Kramer-Marek@icr.ac.uk

3 Cancer Section, Developmental Biology and Cancer Programme, UCL Great Ormond Street Institute of Child Health, London WC1N 1EH, UK; j.anderson@ucl.ac.uk

4 Department of Specialist Neonatal and Pediatric Surgery, Great Ormond Street Hospital for Children NHS Foundation Trust, London WC1N 3JH, UK

* Correspondence: stefano.giuliani@gosh.nhs.uk

check for updates

Citation: Paraboschi, I.; Privitera, L.; Kramer-Marek, G.; Anderson, J.; Giuliani, S. Novel Treatments and Technologies Applied to the Cure of Neuroblastoma. Children 2021, 8, 482. https://doi.org/10.3390/

children 8060482

Academic Editor: Anthony C. Faber

Received: 20 April 2021

Accepted: 1 June 2021

Published: 7 June 2021

Publisher's Note: MDPI stays neutral with regard to jurisdictional claims in published maps and institutional affiliations.

Copyright: (c) 2021 by the authors. Licensee MDPI, Basel, Switzerland. This article is an open access article distributed under the terms and conditions of the Creative Commons Attribution (CC BY) license (https:// creativecommons.org/licenses/by/ $4.0 /)$.
Abstract: Neuroblastoma (NB) is the most common extracranial solid tumour in childhood, accounting for approximately $15 \%$ of all cancer-related deaths in the paediatric population 1 . It is characterised by heterogeneous clinical behaviour in neonates and often adverse outcomes in toddlers. The overall survival of children with high-risk disease is around $40-50 \%$ despite the aggressive treatment protocols consisting of intensive chemotherapy, surgery, radiation therapy and hematopoietic stem cell transplantation2,3. There is an ongoing research effort to increase NB's cellular and molecular biology knowledge to translate essential findings into novel treatment strategies. This review aims to address new therapeutic modalities emerging from preclinical studies offering a unique translational opportunity for NB treatment.

Keywords: Neuroblastoma; Monoclonal Antibodies; Antibody-Drug Conjugates-Based Therapy; Third-Generation Tyrosine Kinase Inhibitor; Drug-Loaded Nanoparticles; cellular immunotherapies; tumour vaccines; radiation therapies; intra-operative treatments

\section{Introduction}

Neuroblastoma (NB) is the most common extracranial solid tumour in childhood, accounting for approximately $15 \%$ of all cancer-related deaths in the paediatric population [1]. It is characterised by heterogeneous clinical behaviour in neonates and often adverse outcomes in toddlers.

The overall survival of children with high-risk disease is around $40-50 \%$ despite the aggressive treatment protocols consisting of intensive chemotherapy, surgery, radiation therapy, and hematopoietic stem cell transplantation $[2,3]$.

There is an ongoing research effort to increase NB's cellular and molecular biology knowledge to translate essential findings into novel treatment strategies. This review aims to address new therapeutic modalities emerging from preclinical studies offering a unique translational opportunity for NB treatment.

\section{Novel Molecules and Nanoparticles}

\subsection{Monoclonal Antibodies ( $m A b s$ )}

Specific mAbs against NB-associated antigens have been investigated as the basis for different immunotherapeutic approaches. Several authors have tried to enhance the efficacy of anti-GD2 mAb ch14.18 (dinutuximab and dinutuximab beta), which is now standard of care for patients with high-risk NB in Europe and North America, by combining its administration with immunologically active molecules (Figure 1) [4,5]. The primary mechanism 
of action of dinutuximab is most commonly presumed to be antibody-dependent cell cytotoxicity (ADCC) mediated by cells such as natural killers (NK), monocytes, macrophages, and neutrophils [6].

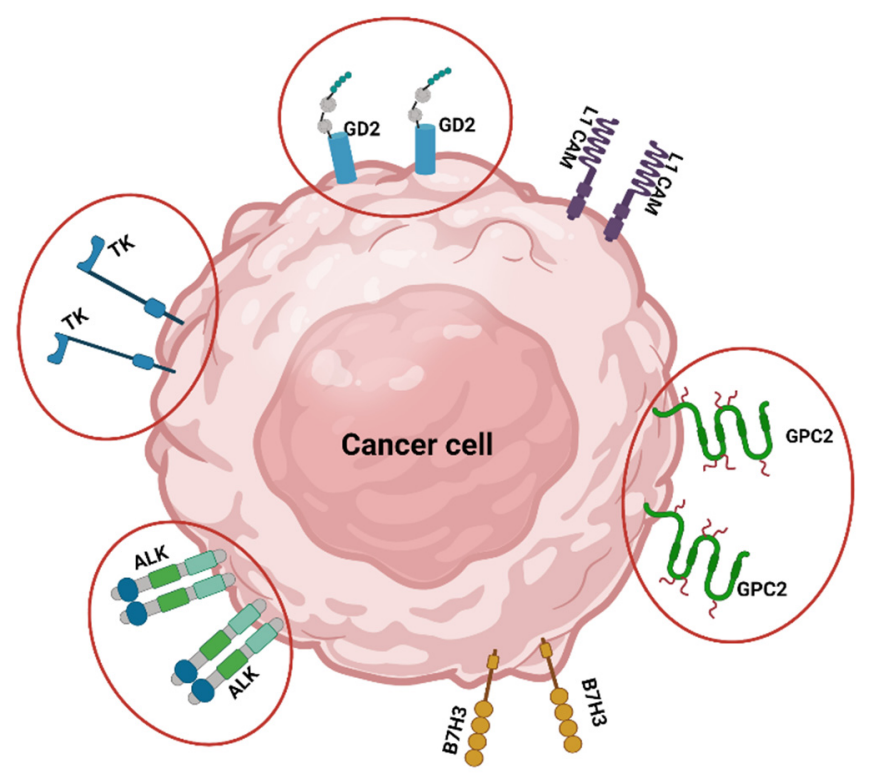

Figure 1. Molecular targets in Neuroblastoma. The image shows 6 different targets: tyrosine kinases (TK); GD2; L1 cell adhesion molecule (L1 CAM); glypican-2 (GPC2); B7H3, and anaplastic lymphoma kinase (ALK). Molecules highlighted in red discussed in paragraph 2.

The induction of immune checkpoints represents an important mechanism used by tumours to escape immune system recognition and growth. NB cells, for example, upregulate Programmed death-ligand 1 (PD-L1) expressed on effector T cells. PD-1 inhibitory receptors have been adopted in combination with ch14.18/CHO-based immunotherapy in preclinical studies. In vivo experiments showed a significant reduction of tumour growth and prolonged survival when PD-L1+/GD2+ NB-bearing mice were treated with ch14.18/CHO combined with anti-PD-1 mAb [4].

Regulatory T cells (Treg), both natural and peripherally converted, represent a crucial mechanism of tumour-related immunosuppression, and they may limit the onset of an efficient anti-tumour immune response. This phenomenon was studied by Croce et al. [7], who demonstrated that the transient depletion of CD4(+) T cells augmented IL-21-based immunotherapy of disseminated NB in syngeneic mice. Moreover, the combined immunotherapy with anti-PD-1/anti-PD-L1 mAbs and anti-CD4 mAbs resulted in a synergistic effect, leading to a significant increase of tumour-free survival in two syngeneic models of disseminated NB [8]. Another study published by Tran et al. [5] showed that the addition of galunisertib, a TGF $\beta$ R1 inhibitor, to adoptive cell therapy with NK cells plus anti-GD2 mAb reduced the tumour growth and increased the survival of NSG mice injected with NB cells (Table 1).

\subsection{Antibody-Drug Conjugates (ADC)s-Based Therapy}

Molecularly targeted approaches have been extensively investigated for NB treatment to lower systemic toxicity and improve clinical outcomes. In particular, ADCs are a rapidly growing class of anticancer drugs that, by combining the targeting properties of $\mathrm{mAbs}$ with potent cytotoxic drugs, have been emerging as efficient therapies against NB.

Amongst the NB-specific cell surface molecules, glypican-2 (GPC2) can be considered an ideal immunotherapeutic target being overexpressed on high-risk NBs and restricted on normal childhood tissues (Figure 1). This finding was exploited to develop the D3-GPC2PBD molecule, consisting of an IgG1 anti-GPC2 mAb conjugated to pyrrolobenzodiazepine (PBD) dimers, a class of potent cytotoxic DNA minor groove interstrand crosslinking 
agents. The D3-GPC2-PBD mediated potent dose-dependent cytotoxicity in an antigenand concentration-dependent manner in vitro and was similarly efficacious and safe for in vivo NB murine models [9].

Another target for ADCs therapy has been the anaplastic lymphoma kinase (ALK) protein. ALK is widely expressed in most high-risk primary NB tumours regardless of the mutation status, particularly in patients with advanced-stage and MYCN-amplified disease [10]. In detail, a highly specific ALK mAb (CDX-0125) has been conjugated with thienoindole (TEI), a DNA minor groove alkylating agent, to promotes cell death in ALKexpressing NB models [10].

Although initially only tumour-associated antigens were considered ideal targets for ADCs, more recently, the stromal components of the tumour microenvironment (TME) also have been explored as potentially actionable targets. In particular, tumour-derived extracellular vesicles (EVs) have been used as a drug delivery system capable of altering the TME and modulating cancer development. Because the EVs derived by most NB cells are highly enriched by the galectin-3-binding protein (LGALS3BP), a non-internalising LGALS3BP ADC called 1959-sss/DM3 was developed to selectively target NB cell lines. The 1959-sss/DM3 molecule was made by combining an engineered humanised antiLGALS3BP Ab with DM3, a chemical derivative of maytansine with a cell-killing potency in the picomolar range. Interestingly, preclinical mouse models showed high efficacy in eradicating both orthotopic and metastatic NBs [11] (Table 1).

\subsection{Third-Generation Tyrosine Kinase Inhibitor (TKi)}

Tyrosine kinases (TKs) are a subgroup of the protein kinases family that play a pivotal role in regulating cellular activities, resulting in tumourigenesis and cancer progression in NB [12]. The inhibition of TKs has been investigated as a promising strategy to increase the apoptotic rate in NB cell lines. In this regard, Whittle et al. [13] proved that ponatinib (PON), a multi-targeted tyrosine kinase inhibitor, exerted significant anti-angiogenetic effects in orthotopic xenograft mouse models of human NB, significantly inhibiting their growth and vascularity for in vivo experiments. Moreover, $\mathrm{Li}$ et al. [12] found that PON significantly inhibits NB cell proliferation and induces cell apoptosis by blocking FGFR1-activated $\mathrm{PI} 3 \mathrm{~K} / \mathrm{AKT} / \mathrm{mTOR}$ and JAK/STAT3 signal pathways.

Because an increased rate of resistance to PON was reported in either preclinical or clinical settings, with autophagy being the primarily responsible mechanism, Corallo et al. [14] investigated its cytoprotective role in NB cells during treatment with PON. Interestingly, their data confirmed a PON-dependent activation of autophagy, both in vitro and in vivo, and highlighted the function of autophagy inhibitors, such as chloroquine, as effective adjuvants for enhancing the cytotoxic effects of current chemotherapy protocols (Table 1).

\subsection{Drug-Loaded Nanoparticles}

New approaches based on targeted drug delivery may improve the efficacy and decrease the toxicity of NB treatment. In this respect, innovative therapies based on the use of liposomes loaded with anticancer agents and functionalised with peptides, capable of recognising NB cells and/or tumour-associated endothelial cells, are of particular interest. Because of their composition, liposomes can carry both hydrophilic and hydrophobic molecules. The extent of action of the drug will depend upon its physicochemical characteristics and composition of lipid. The mechanism of drug molecule delivery is based on the fusion of the lipid bilayers with other cell bilayers, such as the cell membrane, to release the liposomal content. As cancer cells consume large amounts of fats to fill the rapid growth requirement, they recognise the liposomes and absorb them. Once the anticancer drugs are released from the liposome into the site, cancer cells are killed by the drug [15]. To optimise the use of these nanoparticles, in addition to the "enhanced permeability and retention effect" related to the leaky vessels typically present in tumours, different strategies have been adopted to overcome the many physiological barriers present in tumour tissues (i.e., enzymatic degradation, phagocytes of the reticuloendothelial system 
(RES), molecular efflux pumps). In detail, liposomal vectors can be functionalised with tumour-homing and tumour-penetrating peptides, which help anticancer drugs penetrate the tumour, increasing their therapeutic effects (Figure 2) [16].

Table 1. Novel molecules and nanoparticles investigated in preclinical studies focusing on NB treatments.

\begin{tabular}{|c|c|c|c|}
\hline Author, Year & Title & Investigated Treatment & Results \\
\hline \multicolumn{4}{|c|}{ Monoclonal Antibodies } \\
\hline Siebert N et al. [4], 2017 & $\begin{array}{l}\text { PD-1 blockade augments anti-NB immune } \\
\text { response induced by anti-GD2 antibody } \\
\text { ch14.18/CHO }\end{array}$ & ch14.18/CHO + anti-PD-1 Ab & $\begin{array}{l}\text { ch14.18/CHO + anti-PD-1 Ab results in } \\
\text { synergistic treatment effects in mice, } \\
\text { representing a new effective treatment } \\
\text { strategy against GD2-positive NBs. }\end{array}$ \\
\hline Croce M et al. [7], 2009 & $\begin{array}{l}\text { Transient depletion of CD4+ T cells augments } \\
\text { IL-21-based immunotherapy of disseminated } \\
\text { NB in syngeneic mice }\end{array}$ & anti-CD4 $\mathrm{Ab}$ & $\begin{array}{l}\text { Anti-CD4 Ab potentiated IL-21-based } \\
\text { immunotherapy by removing Treg cells, their } \\
\text { precursors and other CD4+ cell subsets. This } \\
\text { allows the development of an IL-21-driven } \\
\text { CD8+ Tcell response, which mediates } \\
\text { NB rejection. }\end{array}$ \\
\hline Rigo V et al. [8], 2017 & $\begin{array}{c}\text { Combined immunotherapy } \\
\text { withanti-PDL-1/PD-1 and anti-CD4 } \\
\text { antibodies cure syngeneic disseminated NB }\end{array}$ & anti-PD-1/PD-L1 Ab & $\begin{array}{l}\text { The combined use of anti-PD-1+ anti-CD4 Ab } \\
\text { mediated a potent, CD8-dependent, } \\
\text { synergistic effect leading to the elongation of } \\
\text { mice's tumour-free survival, complete tumour } \\
\text { regression, and durable anti-NB immunity. }\end{array}$ \\
\hline Tran et al. [5], 2017 & $\begin{array}{c}\text { TGFßR1 Blockade with Galunisertib } \\
\text { (LY2157299) Enhances Anti-NB Activity of } \\
\text { Anti-GD2 Antibody Dinutuximab (ch14.18) } \\
\text { with Natural Killer Cells }\end{array}$ & $\begin{array}{c}\text { ch14.18 + TGF } \beta R 1 \text { inhibitor } \\
\text { (Galunisertib) }\end{array}$ & $\begin{array}{l}\text { Galunisertib suppresses the activation of } \\
\text { SMAD2 in NBs and aNK cells, restores NK } \\
\text { cytotoxic mechanisms, and increases the } \\
\text { efficacy of ch14.18 with aNK cells against NBs. }\end{array}$ \\
\hline \multicolumn{4}{|c|}{ Antibody-Drug Conjugates (Adc)S-Based Therapy } \\
\hline Bosse KR et al. [9], 2017 & $\begin{array}{c}\text { Identification of GPC2 as an oncoprotein and } \\
\text { candidate immunotherapeutic target in } \\
\text { high-risk NB }\end{array}$ & GPC2 targeting ADC & $\begin{array}{l}\text { A GPC2 directed ADC proved to be cytotoxic } \\
\text { to GPC2-expressing NB cells in vitro and } \\
\text { in vivo. }\end{array}$ \\
\hline Sano R et al. [10], 2019 & $\begin{array}{l}\text { An antibody-drug conjugate directed to the } \\
\text { ALK receptor demonstrates efficacy in } \\
\text { preclinical models of NB }\end{array}$ & $\begin{array}{l}\text { ALK targeting ADC } \\
\text { (CDX-0125-TEI) }\end{array}$ & $\begin{array}{l}\text { CDX-0125-TEI exhibited efficient antigen } \\
\text { binding, internalisation and cytotoxicity in } \\
\text { cells with different ALK expression. In vivo } \\
\text { studies showed that CDX-0125-TEI is effective } \\
\text { against ALK wild-type and mutant } \\
\text { patient-derived xenograft models. }\end{array}$ \\
\hline Capone E et al. [11], 2020 & $\begin{array}{l}\text { Targeting vesicular LGALS3BP by an } \\
\text { antibody-drug conjugate as a novel } \\
\text { therapeutic strategy for NB }\end{array}$ & $\begin{array}{l}\text { LGALS3BP targeting ADC } \\
\text { (1959-sss/DM3) }\end{array}$ & $\begin{array}{l}\text { LGALS3BP targeting ADC can cure mice with } \\
\text { established NB tumours in pseudometastatic, } \\
\text { orthotopic and PDX models. }\end{array}$ \\
\hline \multicolumn{4}{|c|}{ Third-Generation Tyrosine Kinase Inhibitor (Tki) } \\
\hline Li et al. [12], 2017 & $\begin{array}{c}\text { Novel multiple tyrosine kinase inhibitor } \\
\text { ponatinib inhibits bFGF- activated signalling } \\
\text { in NB cells and suppresses NB growth in vivo }\end{array}$ & Ponatinib & $\begin{array}{l}\text { Ponatinib can inhibit tumour growth as a } \\
\text { single agent or combined with other } \\
\text { therapeutic agents, such as doxorubicin. }\end{array}$ \\
\hline Whittle et al. [13], 2016 & $\begin{array}{l}\text { The novel kinase inhibitor ponatinib is an } \\
\text { effective anti-angiogenic agent against NB. }\end{array}$ & Ponatinib & $\begin{array}{l}\text { Ponatinib reduces NB cell viability in vitro } \\
\text { and reduces tumour growth and vascularity } \\
\text { in vivo. }\end{array}$ \\
\hline Corallo et al. [14], 2020 & $\begin{array}{l}\text { Autophagic flux inhibition enhances } \\
\text { cytotoxicity of the receptor tyrosine kinase } \\
\text { inhibitor ponatinib. }\end{array}$ & Ponatinib & $\begin{array}{l}\text { Inhibition of autophagic flux by CQ restores } \\
\text { the cytotoxic potential of PON. In vivo, the use } \\
\text { of CQ as adjuvant therapy significantly } \\
\text { improves the anti-tumour effects obtained by } \\
\text { ponatinib, leading to ulterior reduction of } \\
\text { tumour sizes. }\end{array}$ \\
\hline \multicolumn{4}{|c|}{ Drug-Loaded Nanoparticles } \\
\hline Pastorino F et al. [17], 2008 & $\begin{array}{l}\text { Enhanced anti-tumour efficacy of } \\
\text { clinical-grade vasculature-targeted } \\
\text { liposomal doxorubicin. }\end{array}$ & $\begin{array}{l}\text { CD13-targeted liposomal } \\
\text { doxorubicin }\end{array}$ & $\begin{array}{l}\text { TVT-DOX proves to be effective in reducing } \\
\text { cell proliferation, blood vessel density, and } \\
\text { microvessel area, showing increased } \\
\text { cell apoptosis. }\end{array}$ \\
\hline Di Paolo et al. [18], 2020 & $\begin{array}{l}\text { Combined Replenishment of miR-34a and } \\
\text { let-7b by targeted nanoparticles inhibits } \\
\text { tumour growth in NB preclinical models. }\end{array}$ & $\begin{array}{l}\text { GD2-targeted liposomes } \\
\text { entrapping miR-34a and let-7b }\end{array}$ & $\begin{array}{l}\text { The replenishment of miR-34a and let- } 7 \mathrm{~b} \text { by } \\
\text { NB-targeted nanoparticles, individually and } \\
\text { more powerfully in combination, significantly } \\
\text { reduces cell division, proliferation, } \\
\text { neoangiogenesis, and tumour growth, induces } \\
\text { apoptosis in orthotopic xenografts, and } \\
\text { improves mice survival in } \\
\text { pseudometastatic models. }\end{array}$ \\
\hline
\end{tabular}

Abbreviations. Ab: antibody; NB: neuroblastoma; PD-1: programmed death-1; PD-L1: programmed death-ligand 1; SMAD: small mother against decapentaplegic; aNK: activated natural killer; GPC2: glypican-2; ADC: antibody-drug conjugate; ALK: anaplastic lymphoma kinase; PDX: patient-derived xenograft; CQ: chloroquine; TVT-DOX: Targeted liposomal doxorubicin. 

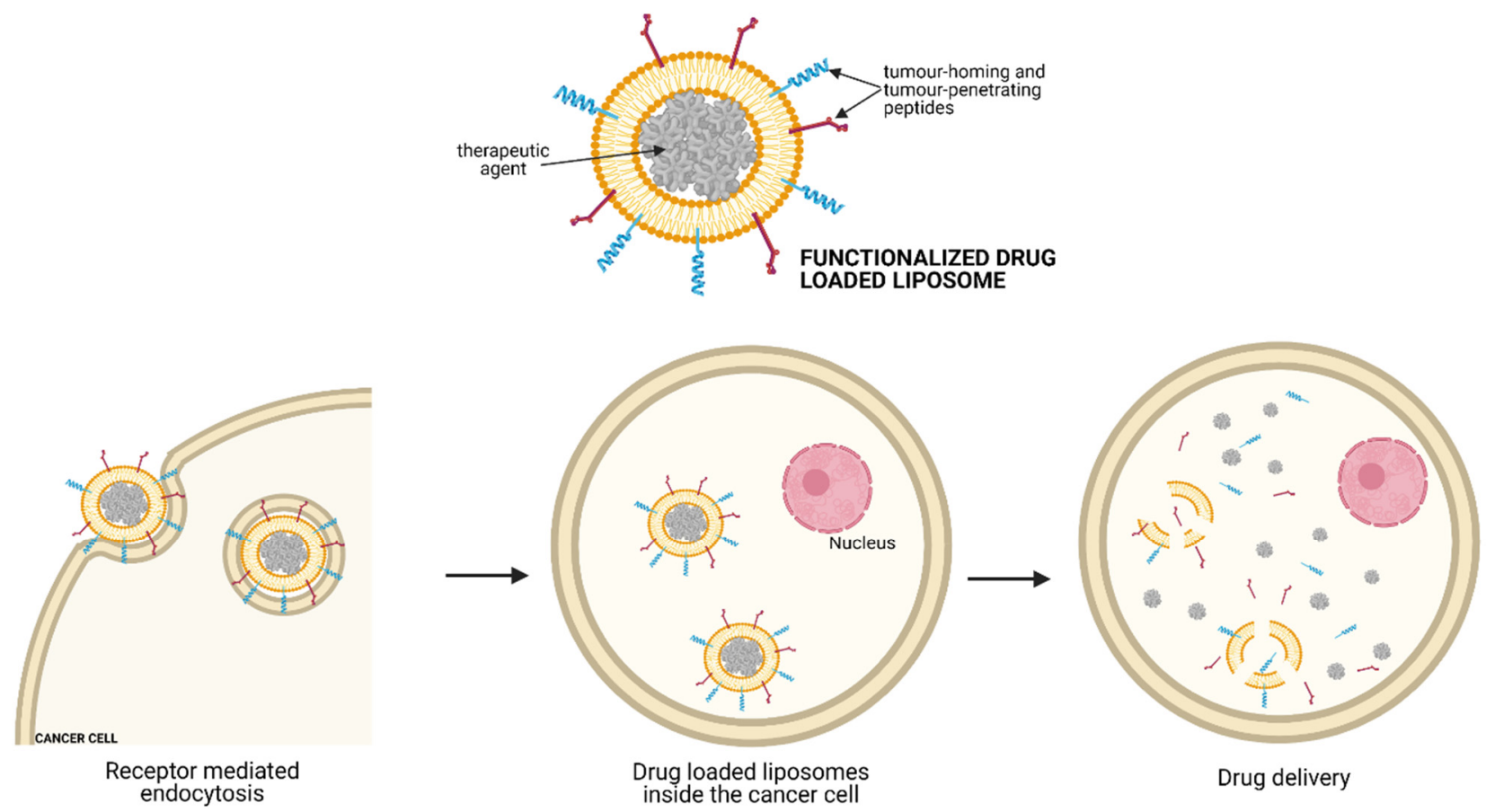

Figure 2. Mechanism of action of drug-loaded liposomes. Liposomes are loaded with anticancer agents and functionalised with peptides capable of recognising the cell of interest. Once the liposome fuses its lipid bilayers with other cell bilayers, the anticancer drugs are released from the liposome into the cancer cells, exhibiting their cytotoxic action.

In the literature, several formulations have been described, for example, containing doxorubicin (DXR), fenretinide (HPR) or bortezomib (BTZ), decorated with peptides capable of recognising receptors in the tumour vasculature and/or in NB cells [16]. DXRentrapped liposomes have been functionalised with NGR-containing peptides, capable of recognising CD13 expressed by NB endothelial cells, to deliver liposomal DXT to tumour vessels [17]. As a result, their anticancer effects were higher than the untargeted DXRliposomal formulations, with no systemic toxicity.

The therapeutic potential of novel lipidic nanoparticles entrapping miR-mimics has also been explored to reactivate multiple genes/pathways inhibited in tumour settings. Di Paolo et al. [18] developed an effective nanocarrier for the systemic administration of miR-34a and let-7b, two tumour suppressor (TS) miRNAs depleted in NB tumours. Their findings demonstrated that the targeted liposome administration of miR-34a and let- $7 \mathrm{~b}$ mimics significantly increased the survival of pseudo metastatic NB mice (models able to mimic the typical metastatic spread in advanced stages) and significantly reduced cell proliferation, neo-angiogenesis, and tumour growth in orthotopic models of NB (Table 1).

\section{Cellular Immunotherapy}

Immunotherapies based on immune effector cells, able to recognise tumour-associated antigens and exert specific cytotoxicity against tumour cells, are promising approaches investigated in several preclinical studies. Chimeric antigen receptor (CAR) - modified Tcells are genetically engineered T-cells that express a synthetic immunoreceptor consisting of an antigen-binding ectodomain (e.g., single-chain $\mathrm{Fv}(\mathrm{scFv})$ ). This directs them to a particular tumour antigen and signalling domains that trigger T-cell activation and proliferation when the foreign antigen is bound. Specifically, NB cells ubiquitously express the GD2 ganglioside, an attractive tumour-associated antigen for cellular immunotherapy.

In 2008, Pule et al. [19] engineered Epstein-Barr virus (EBV)-specific cytotoxic T lymphocytes (CTLs) to express a chimeric antigen receptor directed to GD2 to see if they would receive optimal co-stimulation after engagement of their receptors, enhancing survival and anti-tumour activity. They found that human virus-specific CAR-CTLs persist in higher numbers and for longer times after administration than $T$ cells expressing the 
same receptor but lacking viral specificity (CAR-ATCs), with tumour regression or necrosis in half of the subjects tested. Following this study, Chrystal U. Louis et al. [20] reported the long term clinical and immunologic consequences of CAR-CTLs and CAR-ATCs in 19 patients with high-risk NB (11 of them being in follow-up for four years from the first study). Their results show that the long-term low-level presence of CAR-expressing T cells is associated with clinical benefits, and that they can induce complete tumour responses in patients with active NB. However, follow-on studies using a third-generation format of the same CAR-T failed to show significant clinical efficacy in patients [21]. Using a different antibody, a phase 1 study by Straathof et al. [22] evaluated 12 children with relapsed or refractory NB treated with escalating doses of second-generation GD2-directed CAR-T cells, increasing intensity of preparative lymphodepletion. Twenty-eight days after the infusion, no patients had an objective clinical response based on the standard radiological response criteria. However, three patients demonstrated regression of soft tissue and bone marrow disease, and two patients experienced grade 2 to 3 cytokine release syndrome.

Bocca et al. [23] further evaluated this by investigating the anti-NB activity of GD2specific CAR T-cells combined with bevacizumab (BEV), a specific mAb against vascular endothelial growth factor (VEGFR), in an orthotopic xenograft model of human NB. When combined with BEV, GD2-CAR T-cells massively infiltrated the tumour mass and secreted interferon- $\gamma$ (IFN- $\gamma$ ), which, in turn, upregulated NB cell expression of PD-L1. Concurrently, tumour infiltrating GD2-CAR T-cells expressed PD-1. PD-L1 silencing or blocking strategies were then advocated to enhance the efficacy of such a combination of therapies.

Another attractive cell source for adoptive cancer immunotherapy in NB is represented by gamma delta T lymphocytes ( $\gamma \delta$ T-cells) due to their innate cytotoxicity. In fact, these cells are able to recognise phosphoantigens, which are natural nonpeptide phosphorylated intermediates of isoprenoid metabolism operating in human cells. Interestingly, tumour cells express one of them at a high level, the isopentenyl pyrophosphate (IPP), especially when exposed to amino bisphosphonates. Thus, tumour cells can be exposed to amino bisphosphonates to let them be recognised and killed by $\gamma \delta$ T-cells. Di Carlo et al. [24] showed in preclinical models of NB that the combined treatment with V $\delta 2+\mathrm{T}$-cells (the most common subset of $\gamma \delta$ T-cells) and zoledronic acid (ZOL) was able to inhibit tumour cell proliferation and angiogenesis and to induce cell apoptosis, supporting their use as a therapeutic strategy for NB patients. Moreover, Fisher et al. [25] showed that the combination of adoptively transferred V $\delta 2+$ T-cells, expanded in vitro with ZOL and IL-2, with dinutuximab and systemic ZOL suppressed tumour growth compared to antibody or $\gamma \delta \mathrm{T}$ cell-free controls in an immunodeficient mouse model of small established GD2expressing NB tumours.

Regarding the employment of cytotoxic T lymphocytes (CTL) and NK cells for antitumour immunotherapy, one of their limits is represented by the downregulation of HLAclass I molecules by NB cells. However, Spel et al. [26] proved that an increase in NB cell immunogenicity was possible upon their exposure to active NK cells, which sensitise NB cells' recognition by CTLs. Further evidence of the potential of NK cell immunotherapy as a successful approach in NB treatment was reported by Castriconi et al. [27], who showed that early repeated injections of polyclonal IL-2-activated NK cells significantly increased the survival and reduced the bone marrow infiltration of NB-bearing NOD/SCID mice. Interestingly, low doses of human recombinant IL-2 or IL-15 further enhanced the therapeutic effects.

Driven by the increasing recognition of the pivotal role of tumour vasculature in the survival and growth of solid tumours, there has been a great interest in developing approaches that target and disrupt the existent tumours' vessels [28,29]. Loi M et al. [30] tagged DXR-loaded liposomes with the CPRECESARSSSRTPSDKY peptide, which targets the aminopeptidase A (APA). The APA is enhanced and active in pericytes associated with tumour blood vessels, and it has been correlated with neoplastic progression [31,32]. What they found in this study is that the combined targeting of both the endothelial and the 
perivascular cells not only increased the disruption of the endothelial wall but also resulted in a statistically significant enhanced anti-tumour effect [30].

Besides tumour blood vessels, liposomal DXR formulations can also be directed explicitly towards tumour cells. In this regard, NB exposure with DXR-loaded Fab' fragments of anti-GD2 immunoliposomes in nude mice leads to significantly greater inhibition of cell proliferation (in vitro), and long-term survival rates approaching $100 \%$ suggested that total inhibition of the metastatic growth of human NB was happening [33].

Finally, the combined use of liposomal DXR tagged with an NGR-containing peptide, and anti-GD2 mAb has been administered sequentially to target both tumour vessels and cancer cells, obtaining a more significant inhibition of NB tumour growth than each formulation given alone. Apart from DXR, sterically stabilised liposomes loaded with HPR have been developed to improve the encapsulated drug's therapeutic efficacy, reducing neoangiogenesis and tumour cell proliferation [18]. Similarly, vascular-targeted-BTZ-loaded liposomal formulations have been employed to effectively inhibit NB growth, minimise side effects, and increase the therapeutic index compared to the free drug [34].

\section{Tumour Vaccines}

The use of tumour cell-based vaccines represents an attractive way of generating anti-NB immunity without increasing the toxicity associated with current radiotherapy and chemotherapy protocols. The vaccines train the immune system to recognise and destroy NB cells after chemotherapy.

In this regard, Bauer et al. [35] designed a multimodal tumour vaccine consisting of irradiated tumour cells infected with the oncolytic IL-12-expressing HSV-1 virus (M002), which produced a stable and specific immunisation in a murine model of intracranial tumour.

Chakrabarti et al. [36] showed that the therapeutic vaccination with neuro-2a cells knock-down for the inhibitor of differentiation protein 2 (Id2- kd) significantly suppressed tumour growth in well-established NB tumours. This anti-tumour effect was even more substantial when combined with checkpoint inhibitors. An increased number of IFN- $\gamma$ producing CD8+ T-cells and the infiltration of cytotoxic CD8+ T cells within the tumour were responsible for the effect of this novel tumour vaccine strategy.

Moreover, Berger et al. [37] reported that the oral gavage of attenuated Salmonella typhimurium (SL7207), carrying recent generated survivin DNA was able to induce a more robust cellular anti-NB immune response than gene gun application or injection of lentivirally transduced bone marrow-derived dendritic cells (DCs) in a syngeneic mouse model of NB.

Similarly, Fest et al. [38] tested a surviving minigene DNA vaccine (pUS-high) administered using SL7207 as a DNA carrier. It proved that this led to complete NB eradication in over $50 \%$ of immunised mice.

Because the first-step enzyme of catecholamine biosynthesis, the human tyrosine hydroxylase (hTH), is an important marker for NB, three DNA vaccine plasmids encoding for human hTHcDNA hTH minigene and hTHcDNA have been administered in combination with IL-12 in syngeneic A/J mice to suppress primary tumour growth and spontaneous metastasis [39].

Gil et al. [40] analysed the ability of therapeutic DC vaccines expressing 47-LDA, a CD166 cross-reactive mimotope of the GD2 ganglioside, to selectively expand adoptively transferred tumour-specific T-cells in lymphodepleted NXS2 NB tumour-bearing syngeneic mice. To deliver the antigenic cassette to the activating Fc gamma receptors, the 47-LDA mimotope was presented to DCs either as a linear polypeptide in conjunction with universal Th epitopes or as a fusion protein with the murine IgG2a Fc fragment (47-LDA-Fcgamma2a). Interestingly, the latter formulation was more effective in the induction of the anti-tumour immune response.

Cheung et al. [41] recently published the results of a phase II trial for a bivalent vaccine with escalating doses of the immunological adjuvant OPT-821, combined with oral $\beta$-glucan. The patient cohort was composed of 102 patients with high-risk NB in 
remission. The words "bivalent vaccine" means that there are two antigens, GD2 and GD3, the carbohydrate antigens prevalent in NB. This vaccine's rationale is that if the patient can make antibodies against the two antigens in the vaccine, they could also selectively kill NB cells by attracting the patient's white blood cells to kill the NB. However, these antigens are poorly immunogenic, so in order for the body to make antibodies against them, they link each antigen to a protein called KLH (keyhole limpet hemocyanin) and mix them with a substance called OPT-821. Their results show that the vaccine plus b-glucan elicited robust antibody responses in patients and that higher anti-GD2-IgG1 title was associated with improved survival.

Toll like receptor 9 (TLR9) agonists, such as synthetic oligonucleotides containing unmethylated $\mathrm{CpG}$ motifs (CpG ODNs), can be used as vaccine adjuvants because they can directly induce the activation and maturation of plasmacytoid DCs and can enhance the differentiation of B cells into antibody-secreting plasma cells [42]. Brignole et al. [43] evaluated the anti-tumour activity of CpG-containing c-myb antisense oligonucleotides encapsulated with GD2-targeted liposomes in two murine xenograft models of NB. They demonstrated that both the direct inhibition of cell growth, mediated by decreased c-myb protooncogene expression and the indirect CpG-dependent immune stimulation by the NK cell-mediated lysis of tumour cells, resulted in the inhibition of tumour growth, leading to long-term survival in NB-bearing mice. Moreover, as IL-10 is an immune-regulatory cytokine known to suppress macrophages and DC function, the combined administration of CpG ODN-containing liposomes and Abs against IL-10R has proved to prolong immune system activation, leading to better therapeutic results in NB xenografts [44].

\section{Radiation Therapy}

Radiation therapy is an essential component of NB treatment and is typically administered to both the primary tumour bed after surgical resection and metastatic sites after induction chemotherapy. However, even after radiation therapy, the loco-regional relapse in these patients is still high, with approximately $50 \%$ of children relapsing and bearing a 5 -year survival of only $8 \%$ [45].

\subsection{Proton Beam Therapy (PBT)}

As NB patients are very young, undergo intensive multi-agent chemotherapy, and the tumour is often close to radiation-sensitive organs, PBT represents a promising alternative to conventional radiotherapy, especially for reducing the treatment burden associated with it. It is also feasible with very little acute and early late toxicity in the susceptible cohort of very young NB patients.

Different studies on PBT for NB have recently been published, with patients showing similar demographics and treatment strategies before irradiation. In these studies, PBT was performed on the pre-operative tumour bed with 21.6-24 Gray (Gy). In this regard, Hill et al. [46] reported a 5-year local control rate of $97 \%$ after a median follow-up time of 48.7 months, while Bagley et al. [47] published a 5-year local control rate of $87 \%$ after a median follow-up of 60.2 months.

In a study published this year, Danny Jazmati et al. [48] performed a retrospective analysis of children with high- or intermediate-risk NB who had PBT of the primary tumour site performed during the first-line therapy. Their protocol consisted of PBT doses ranging from 21.0 to $39.6 \mathrm{~Gy}$. In 39 patients, radiation was given to the pre-operative tumour bed with or without an additional boost in case of residual tumour (five patients received PBT to the MIBG-avid residual at the primary tumour site at the time of PBT). Although the patients received total doses above $30 \mathrm{~Gy}$, in line with the previously mentioned studies, they did not observe relevant toxicity and tumour control rates were high, both for the primary site and the metastases. 


\subsection{Near-Infrared Photoimmunotherapy (NIR-PIT)}

NIR-PIT is a newly developed and highly selective cancer treatment that employs a monoclonal antibody conjugated to a photo-absorber dye (IRDye700DX), which is activated by $690 \mathrm{~nm}$ light (Figure 2). It represents a promising anti-tumour strategy capable of enhancing immunotherapy's therapeutic potential by inducing rapid necrotic/immunogenic cancer cell death. The NIR-PIT, in fact, selectively targets cancer cells and induces antitumour host immunity with re-priming and proliferation of T-cells that react against cancer-specific antigens. In particular, NIR-PIT causes direct (Figure 3-panel B) and indirect (Figure 3-panel C) cell killing because the cell membrane rupture releases tumourspecific antigens into the TME and promotes dendritic cell (DC) maturation, resulting in the presentation of cancer-specific antigens on DCs to naive T cells.

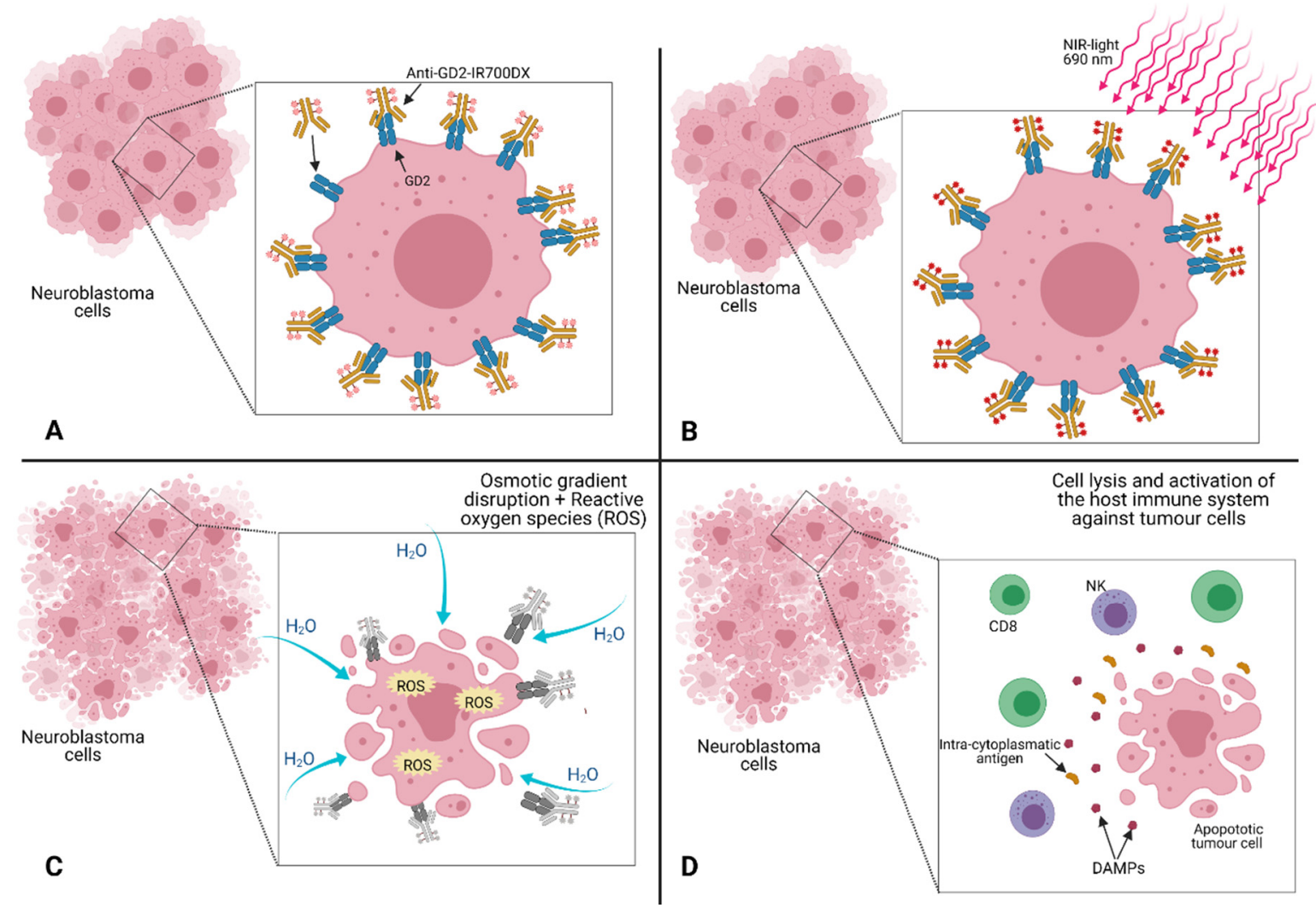

Figure 3. Schematic representation of near-infrared photoimmunotherapy (NIR-PIT) mechanism of action. (A) Specific binding of the anti-GD2 monoclonal antibody (mAb) labelled with IRdye700DX (anti-GD2-IR700DX) to the cancer cell surface GD2 antigen (GD2). (B) Subsequent local exposure to near infrared (NIR) light. (C) The exposure turns on the photochemical "death" switch, resulting in the rapid and highly selective immunogenic cell death (ICD) of targeted cancer cells. (D) The rapid cell lysis leads to release of intra-cytoplasmatic antigens and damage associated molecular patterns (DAMPs) in the extracellular space, leading to the activation of the host immune system against the dying tumour cells.

At the American Association for Cancer Research meeting in 2018, Hiroshi Nouso et al. [49] presented the use of NIR-PIT with an anti-GD2-IR700 as a promising anti-tumour strategy to enhance the therapeutic efficacy of anti-GD2 immunotherapy for high-risk NB. They evaluated the anti-tumour effect of anti-GD2-IR700 on three human NB cell lines, showing that the administration of anti-GD2-IR700 significantly suppressed the cell viability compared to anti-GD2 $\mathrm{mAb}$ when combined with NIR light irradiation. Proceeding further on this line, another study by Yasuhiro Maruoka et al. [50] hypothesised that the administration of IL-15 with cancer cell-targeted NIR-PIT could also inhibit tumour growth by increasing anti-tumour host immunity. To demonstrate this, three syngeneic mouse tumour models underwent combined CD44-targeted NIR-PIT and short-term IL-15 administration. The use of CD44 as a tumour 
target is a well-known marker of cancer stem cells as it is expressed on the cell membrane of several cancers. Their results show that the combination therapy of IL-15 after NIR-PIT inhibited tumour growth, prolonged survival, and increased tumour infiltrating CD8+ T cells more efficiently than NIR-PIT alone. Thus, IL-15 appears to enhance the therapeutic effect of cancer-targeted NIR-PIT.

\subsection{Radioisotope Based Radiation}

Most NBs express the noradrenaline transporter molecule and take up metaiodobezylguanidine (mIBG), which can be radiolabelled with either ${ }^{123}$ I or ${ }^{131}$ I. The ${ }^{131} \mathrm{I}-\mathrm{mIBG}$ therapy is currently used for induction and consolidation treatments, with loco-regional control rates of $84-100 \%$ in case of persistent MIBG-avid metastatic sites [51].

In 2014 Wilson et al. [52] published a review on ${ }^{131}$ I-mIBG therapy for NB in which they analysed the controversial results present in the literature. Overall, the median response rate of ${ }^{131}$ I-mIBG alone was the same as the radiation combined with chemotherapy. However, response rates reported from different relapsed/refractory studies had a great range of variation. Although the response rates to ${ }^{131} \mathrm{I}-\mathrm{mIBG}$ therapy were of clinical significance, there was no evidence of better long-term outcome as measured by event-free survival (EFS) or overall survival (OS). Although the analysis was heterogeneous from the clinical perspective, there are still open questions and uncertainties: how effective is ${ }^{131}$ I-mIBG? Should it be administered alone or in combination with chemotherapy?

Enhancing the therapeutic effect of ${ }^{131}$ I-mIBG treatment might require combining it with different treatment modalities. The advantage of combining other radiotherapy modalities lies in the ability to achieve higher radiation absorbed tumour doses without compromising the dose-limiting organs of each therapy. This field was explored by Aurélien Corroyer-Dulmont et al. [53], who improved the molecular radiotherapy outcome through combination with external beam radiotherapy (EBRT) in a mouse model of NB. In their results, vessel permeability was increased at $24 \mathrm{~h}$ post EBRT, which correlated with an increase in ${ }^{131} \mathrm{I}$-mIBG uptake. Likewise, EBRT administered 7 days after ${ }^{131} \mathrm{I}-\mathrm{mIBG}$ significantly decreased the tumour volume and increased overall survival. This study demonstrates the potential of the combined modality EBRT and ${ }^{131}$ I-mIBG therapy as a useful addition to currently available therapeutic protocols.

\section{Intra-Operative Treatments}

\subsection{Targeted Probes for Surgery}

Surgery represents a cornerstone within the multimodal treatment of NB. The literature supports the idea that a gross total resection is associated with better survival outcomes $[54,55]$. However, performing a radical NB excision is particularly demanding due to the strict adhesion of the tumour to major blood vessels and nerves and the extensive tumour fibrosis resulting from the neoadjuvant chemotherapy. By facilitating the tumour's discrimination from the surrounding normal tissue, fluorescence-guided surgery (FGS) can lower the risk of intra-operative complications and increase the survival rate of children affected by NB.

In this regard, Wellens et al. [56] developed an anti-GD2-specific tracer consisting of the immunotherapeutic anti-GD2 mAb conjugated to the near-infrared I (NIR-I) fluorescent dye IRDye800CW. Using xenograft mouse models of NB, they proved the specific binding of this fluorescent probe in vivo. They defined an optimal dose of $1 \mathrm{nmol}$ and an imaging time window of 4 days after its administration to obtain a better fluorescent signal.

Similarly, Jin et al. [57] prepared RVG peptide and IRDye800CW-conjugated bovine serum albumin-coated triangular gadolinium oxide nanoplates (RVG\&IRDye800-Gd2O3 TNs) both as a targeting MRI agent for the diagnosis of NB and as a fluorescence imaging agent for the guidance of NB surgical removal. Notably, with the guidance of this fluorescent imaging agent, the survival rate of mice bearing orthotopic NB xenografts increased from $0 \%$ to $80 \% 42$ days after surgery compared to the survival associated with conventional surgery. 


\subsection{Fibrin Gels (FBGs)}

Fibrin gels are widely applied in surgery and are well-known vehicles for the local delivery of anticancer agents. They are highly biocompatible, biodegradable, and safe drugreleasing tools that may overcome the problems related to an insufficient drug concentration at the tumour site. FBG is applied following the surgical resection of the tumour. The gel, which contains $\mathrm{CaCO}_{3}$ nanoparticles encapsulated with the immunotherapeutic antibody, is sprayed on the tumour bed to be gradually released into the tissue. The link between the antibody and its target increases the phagocytosis of cancer cells by macrophages and initiates T-cell-mediated anti-tumour response. Furthermore, $\mathrm{CaCO}_{3}$ nanoparticles scavenge $\mathrm{H}^{+}$and elicit an immune-supportive microenvironment after surgery [58] (Figure 4).
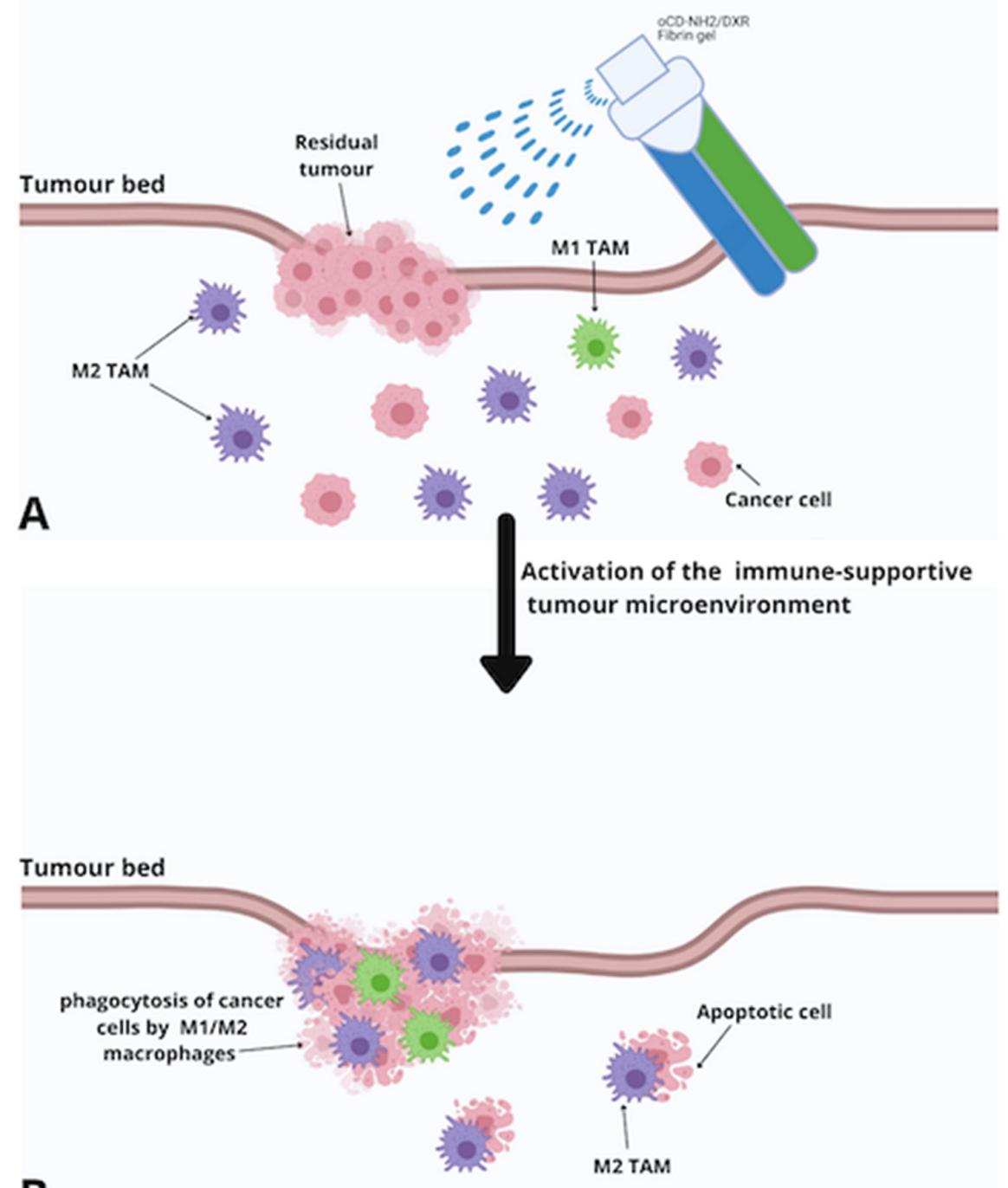

B

Figure 4. Schematic representation of in-situ-sprayed immunotherapeutic fibrin gel. (A) The gel, which contains $\mathrm{CaCO}_{3}$ nanoparticles encapsulated with the immunotherapeutic antibody, is sprayed on the tumour bed to be gradually released into the tissue. (B) $\mathrm{CaCO}_{3}$ nanoparticles scavenge $\mathrm{H}+$ in the surgical wound site, eliciting an immune-supportive tumour microenvironment after surgery. Cyclodextrins (CD) are used to improve the solubility, delivery, and bioavailability of different drugs, such as doxorubicin, leading to higher drug uptake by cells' antiproliferative and apoptotic activity. Abbreviations: TAM, tumour-associated macrophage. oCD-NH2/DXR, doxorubicin administered in association with functionalised cyclodextrins. 
Vitale et al. [59] evaluated FBGs as a loco-regional therapy in NB with doxorubicin administered in association with functionalised cyclodextrins (oCD-NH2/DXR) in two orthotopic NB models. Cyclodextrins (CD) are used to improve the solubility, delivery, and bioavailability of different drugs, such as doxorubicin, leading to higher drug uptake by cells' antiproliferative and apoptotic activity. Their results indicated that FBGs loaded with oCD-NH2/DXR had significantly higher anti-tumour activity than the intravenous administration of free DXR applied in the visceral space above the adrenal gland, either pre or post tumour removal. The authors also investigated the marked vesicant and necrotising effects of Dox, limiting its application for loco-regional therapy, by performing histological analysis of different organs at autopsy. Damage related to the application of FBGs loaded with oCD-NH2/Dox was observed in none of the cases, confirming the complete reversibility of sporadic tissue damage observed 6 days after the administration.

The same authors also compared the therapeutic index of FBGs loaded with two effective liposomal doxorubicin formulations (LDFs), Caelyx and Myocet. They evaluated in vivo the local toxicity and anti-tumour activities of FBGs overlaying on the tumour surface, showing that FBGs loaded with Myocet, administered as neoadjuvant or adjuvant treatment, had lower general and local toxicities compared to gels loaded with Caelyx, free DXR, or compared to i.v DXR [60].

\section{Conclusions}

Targeted molecules and nanoparticles, specific cellular immunotherapies, tumour vaccines, radiation therapies, and intra-operative treatments are some of the novel strategies currently under investigation to increase the survival of NB patients. This review aimed to address these new therapeutic modalities, which offer a unique translational opportunity for NB treatment.

Author Contributions: Conceptualization, S.G. and J.A.; methodology, S.G.; formal analysis, I.P., L.P.; investigation, I.P., L.P.; data curation, S.G., G.K.-M., J.A.; writing—original draft preparation, I.P., L.P.; writing-review and editing, S.G., G.K.-M., J.A.; supervision, S.G. All authors have read and agreed to the published version of the manuscript.

Funding: Medical Research Council UK Clinical Academic Research Partnership (grant number MR/T005491/1) and the Wellcome/EPSRC Centre for Interventional and Surgical Sciences (WEISS, grant number 203145Z/16/Z).

Institutional Review Board Statement: Not applicable.

Informed Consent Statement: Not applicable.

Acknowledgments: This work was supported by the Medical Research Council UK Clinical Academic Research Partnership (PI Stefano Giuliani, grant number MR/T005491/1) and by the Wellcome/EPSRC Centre for Interventional and Surgical Sciences (WEISS, grant number 203145Z/16/Z) at the University College London, United Kingdom.

Conflicts of Interest: The authors declare no conflict of interest.

\section{References}

1. Maris, J.M. Recent Advances in Neuroblastoma. N. Engl. J. Med. 2010, 362, 2202-2211. [CrossRef]

2. Gatta, G.; Botta, L.; Rossi, S.; Aareleid, T.; Bielska-Lasota, M.; Clavel, J.; Dimitrova, N.; Jakab, Z.; Kaatsch, P.; Lacour, B.; et al. Childhood cancer survival in Europe 1999-2007: Results of EUROCARE-5-A population-based study. Lancet Oncol. 2014, 15, 35-47. [CrossRef]

3. Tas, M.L.; Reedijk, A.M.J.; Karim-Kos, H.E.; Kremer, L.C.M.; Vand de Ven, C.P.; Dierselhuis, M.P.; Van Eijkelenburg, N.K.A.; Van Grotel, M.; Kraal, K.C.J.M.; Peek, A.M.L.; et al. Neuroblastoma between 1990 and 2014 in the Netherlands: Increased incidence and improved survival of high-risk Neuroblastoma. Eur. J. Cancer 2020, 124, 47-55. [CrossRef]

4. Siebert, N.; Zumpe, M.; Jüttner, M.; Troschke-Meurer, S.; Lode, H.N. PD-1 blockade augments anti-neuroblastoma immune response induced by anti-GD $\mathrm{G}_{2}$ antibody ch14.18/CHO. Oncoimmunology 2017, 6, e1343775. [CrossRef]

5. Tran, H.C.; Wan, Z.; Sheard, M.A.; Sheard, M.A.; Sun, J.; Jackson, J.R.; Malvar, J.; Xu, Y.; Wang, L.; Sposto, R.; et al. TGFßR1 Blockade with Galunisertib (LY2157299) Enhances Anti-Neuroblastoma Activity of the Anti-GD2 Antibody Dinutuximab (ch14.18) with Natural Killer Cells. Clin. Cancer Res. 2017, 23, 804-813. [CrossRef] [PubMed] 
6. Zeng, Y.; Fest, S.; Kunert, R.; Katinger, H.; Pistoia, V.; Michon, J.; Lewis, G.; Ladenstein, R.; Lode, H.N. Anti-neuroblastoma effect of ch14.18 antibody produced in CHO cells is mediated by NK-cells in mice. Mol. Immunol. 2005, 42, 1311-1319. [CrossRef] [PubMed]

7. Croce, M.; Corrias, M.V.; Orengo, A.M.; Brizzolara, A.; Carlini, B.; Borghi, M.; Rigo, V.; Pistoia, V.; Ferrini, S. Transient depletion of CD4+ T cells augments IL-21-based immunotherapy of disseminated Neuroblastoma in syngeneic mice. Int. J. Cancer 2009, 127, 1141-1150. [CrossRef]

8. Rigo, V.; Emionite, L.; Daga, A.; Astigiano, S.; Corrias, M.V.; Quintarelli, C.; Locatelli, F.; Ferrini, S.; Croce, M. Combined immunotherapy with anti-PDL-1/PD-1 and anti-CD4 antibodies cures syngeneic disseminated Neuroblastoma. Sci. Rep. 2017, 7, 14049. [CrossRef]

9. Bosse, K.R.; Raman, P.; Zhu, Z.; Lane, M.; Martinez, D.; Heitzeneder, S.; Rathi, K.S.; Kendersky, N.M.; Randall, M.; Donovan, L.; et al. Identification of GPC2 as an Oncoprotein and Candidate Immunotherapeutic Target in High-Risk Neuroblastoma. Cancer Cell 2017, 32, 295-309. [CrossRef] [PubMed]

10. Sano, R.; Krytska, K.; Larmour, C.E.; Raman, P.; Martinez, D.; Ligon, G.F.; Lillquist, J.S.; Cucchi, U.; Orsini, P.; Rizzi, S.; et al. An antibody-drug conjugate directed to the ALK receptor demonstrates efficacy in preclinical models of Neuroblastoma. Sci. Transl. Med. 2019, 11, eaau9732. [CrossRef] [PubMed]

11. Capone, E.; Lamolinara, A.; Pastorino, F.; Gentile, R.; Ponziani, S.; Di Vittorio, G.; D'Agostino, D.; Bibbò, S.; Rossi, C.; Piccolo, E.; et al. Targeting Vesicular LGALS3BP by an Antibody-Drug Conjugate as Novel Therapeutic Strategy for Neuroblastoma. Cancers 2020, 12, 2989. [CrossRef]

12. Li, H.; Wang, Y.; Chen, Z.; Lu, J.; Pan, J.; Yu, Y.; Zhao, Y.; Zhang, H.; Hu, T.; Liu, Q.; et al. Novel multiple tyrosine kinase inhibitor ponatinib inhibits bFGF-activated signaling in neuroblastoma cells and suppresses neuroblastoma growth in vivo. Oncotarget 2017, 8, 5874-5884. [CrossRef]

13. Whittle, S.B.; Patel, K.; Zhang, L.; Woodfield, S.E.; Du, M.; Smith, V.; Zage, P.E. The novel kinase inhibitor ponatinib is an effective anti-angiogenic agent against Neuroblastoma. Investig. New Drugs 2016, 34, 685-692. [CrossRef]

14. Corallo, D.; Pastorino, F.; Pantile, M.; Mariotto, E.; Caicci, F.; Viola, G.; Ponzoni, M.; Tonini, G.P.; Aveic, S. Autophagic flux inhibition enhances cytotoxicity of the receptor tyrosine kinase inhibitor ponatinib. J. Exp. Clin. Cancer Res. 2020, $39,195$. [CrossRef] [PubMed]

15. Yadav, D.; Sandeep, K.; Pandey, D.; Dutta, R.K. Liposomes for Drug Delivery. J. Biotechnol. Biomater. 2017, 7. [CrossRef]

16. Pastorino, F.; Brignole, C.; Di Paolo, D.; Perri, P.; Curnis, F.; Corti, A.; Ponzoni, M. Overcoming Biological Barriers in Neuroblastoma Therapy: The Vascular Targeting Approach with Liposomal Drug Nanocarriers. Small 2019, 15, e1804591. [CrossRef]

17. Pastorino, F.; Di Paolo, D.; Piccardi, F.; Nico, B.; Ribatti, D.; Daga, A.; Baio, G.; Neumaier, C.E.; Brignole, C.; Loi, M.; et al. Enhanced antitumor efficacy of clinical-grade vasculature-targeted liposomal doxorubicin. Clin. Cancer Res. 2008, 14, 7320-7329. [CrossRef] [PubMed]

18. Di Paolo, D.; Pastorino, F.; Brignole, C.; Corrias, M.V.; Emionite, L.; Cilli, M.; Tamma, R.; Priddy, L.; Amaro, A.; Ferrari, D.; et al. Combined Replenishment of miR-34a and let-7b by Targeted Nanoparticles Inhibits Tumor Growth in Neuroblastoma Preclinical Models. Small 2020, 16, 1906426. [CrossRef] [PubMed]

19. Pule, M.A.; Savoldo, B.; Myers, G.D.; Rossig, C.; Russel, H.V.; Dotti, G.; Huls, M.H.; Liu, E.; Gee, A.P.; Mei, Z.; et al. Virus-specific T cells engineered to coexpress tumor-specific receptors: Persistence and antitumor activity in individuals with Neuroblastoma. Nat. Med. 2008, 14, 1264-1270. [CrossRef]

20. Louis, C.U.; Savoldo, B.; Dotti, G.; Pule, M.; Yvon, E.; Myers, G.D.; Rossig, C.; Russel, H.V.; Diouf, O.; Liu, E.; et al. Antitumor activity and long-term fate of chimeric antigen receptor-positive T cells in patients with Neuroblastoma. Blood 2011, 118, 6050-6056. [CrossRef]

21. Heczey, A.; Louis, C.U.; Savoldo, B.; Dakhova, O.; Durett, A.; Grilley, B.; Liu, H.; Wu, M.F.; Mei, Z.; Gee, A.; et al. CAR T Cells Administered in Combination with Lymphodepletion and PD-1 Inhibition to Patients with Neuroblastoma. Mol. Ther. 2017, 25, 2214-2224. [CrossRef]

22. Straathof, K.; Flutter, B.; Wallace, R.; Jain, N.; Loka, T.; Depani, S.; Wright, G.; Thomas, S.; Cheung, G.W.K.; Gileadi, T.; et al. Antitumor activity without on-target off-tumor toxicity of GD2-chimeric antigen receptor $\mathrm{T}$ cells in patients with Neuroblastoma. Sci. Transl. Med. 2020, 12, eabd6169. [CrossRef]

23. Bocca, P.; Di Carlo, E.; Caruana, I.; Emionite, L.; Cilli, M.; De Angelis, B.; Quintarelli, C.; Pezzolo, A.; Raffaghello, L.; Morandi, F.; et al. Bevacizumab-mediated tumor vasculature remodelling improves tumor infiltration and antitumor efficacy of GD2-CAR T cells in a human Neuroblastoma preclinical model. Oncoimmunology 2018, 7, e1378843. [CrossRef]

24. Di Carlo, E.; Bocca, P.; Emionite, L.; Cilli, M.; Cipollone, G.; Morandi, F.; Raffaghello, L.; Pistoia, V.; Prigione, I. Mechanisms of the Antitumor Activity of Human V $\gamma 9 \mathrm{~V} \delta 2 \mathrm{~T}$ Cells in Combination with Zoledronic Acid in a Preclinical Model of Neuroblastoma. Mol. Ther. 2013, 21, 1034-1043. [CrossRef] [PubMed]

25. Fisher, J.P.H.; Flutter, B.; Wesemann, F.; Frosch, J.; Rossig, C.; Gustafsson, K.; Anderson, J. Effective combination treatment of GD2-expressing Neuroblastoma and Ewing's sarcoma using anti-GD2 ch14.18/CHO antibody with V $\gamma 9 \mathrm{~V} \delta 2+\gamma \delta \mathrm{T}$ cells. Oncoimmunology 2016, 5, e1025194. [CrossRef] [PubMed]

26. Spel, L.; Boelens, J.-J.; van der Steen, D.M.; Blokland, N.J.G.; Van Noesel, M.M.; Molenaar, J.J.; Heemskerk, M.H.M.; Boes, M.; Nierkens, S. Natural killer cells facilitate PRAME-specific T-cell reactivity against Neuroblastoma. Oncotarget 2015, 6, 35770-35781. [CrossRef] [PubMed] 
27. Castriconi, R.; Dondero, A.; Cilli, M.; Ognio, E.; Pezzolo, A.; De Giovanni, B.; Gambini, C.; Pistoia, V.; Moretta, L.; Moretta, A.; et al. Human NK cell infusions prolong survival of metastatic human Neuroblastoma-bearing NOD/scid mice. Cancer Immunol. Immunother. 2007, 56, 1733-1742. [CrossRef]

28. Siemann, D.W.; Chaplin, D.J.; Horsman, M.R. Vascular-targeting therapies for treatment of malignant disease. Cancer 2004, 100, 2491-2499. [CrossRef]

29. Chaplin, D.J.; Horsman, M.R.; Siemann, D.W. Current development status of small-molecule vascular disrupting agents. Curr. Opin. Investig. Drugs 2006, 7, 522-528.

30. Loi, M.; Marchiò, S.; Becherini, P.; Di Paolo, D.; Soster, M.; Curnis, F.; Brignole, C.; Pagna, G.; Perri, P.; Caffa, I. Combined targeting of perivascular and endothelial tumor cells enhances anti-tumor efficacy of liposomal chemotherapy in Neuroblastoma. J. Control. Release 2010, 145, 66-73. [CrossRef] [PubMed]

31. Marchiò, S.; Lahdenranta, J.; Schlingemann, R.O.; Valdembri, D.; Wesseling, P.; Arap, M.A.; Hajitou, A.; Ozawa, M.G.; Trepel, M.; Giordano, R.J.; et al. Aminopeptidase A is a functional target in angiogenic blood vessels. Cancer Cell 2004, 5, 151-162. [CrossRef]

32. Schlingemann, R.O.; Oosterwijk, E.; Wesseling, P.; Rietveld, F.J.; Ruiter, D.J. Aminopeptidase a is a constituent of activated pericytes in angiogenesis. J. Pathol. 1996, 179, 436-442. [CrossRef]

33. Pastorino, F.; Brignole, C.; Marimpietri, D.; Sapra, P.; Moase, E.H.; Allen, T.M.; Ponzoni, M. Doxorubicin-loaded Fab’ Fragments of Anti-disialoganglioside Immunoliposomes Selectively Inhibit the Growth and Dissemination of Human Neuroblastoma in Nude Mice. Cancer Res. 2003, 63, 86.

34. Zuccari, G.; Milelli, A.; Pastorino, F.; Loi, M.; Petretto, A.; Parise, A.; Marchetti, C.; Minarini, A.; Cilli, M.; Emionite, L.; et al. Tumor vascular targeted liposomal-bortezomib minimises side effects and increases therapeutic activity in human Neuroblastoma. J. Control. Release 2015, 211, 44-52. [CrossRef]

35. Bauer, D.F.; Pereboeva, L.; Gillespie, G.Y.; Cloud, G.A.; Elzafarany, O.; Langford, C.; Market, J.M.; Lawrence, S.L. Effect of HSV-IL12 Loaded Tumor Cell-Based Vaccination in a Mouse Model of High-Grade Neuroblastoma. J. Immunol. Res. 2016, 2016, 2568125. [CrossRef] [PubMed]

36. Chakrabarti, L.; Morgan, C.; Sandler, A.D.; Bai, X. Combination of Id2 Knockdown Whole Tumor Cells and Checkpoint Blockade: A Potent Vaccine Strategy in a Mouse Neuroblastoma Model. PLoS ONE 2015, 10, e0129237. [CrossRef] [PubMed]

37. Berger, E.; Soldati, R.; Huebener, N.; Hohn, O.; Stermann, A.; Durmus, T.; Lobitz, S.; Zenclussen, A.C.; Christiansen, H.; Lode, H.N.; et al. Salmonella SL7207 application is the most effective DNA vaccine delivery method for successful tumor eradication in a murine model for Neuroblastoma. Cancer Lett. 2013, 331, 167-173. [CrossRef] [PubMed]

38. Fest, S.; Huebener, N.; Bleeke, M.; Durmus, T.; Stermann, A.; Woehler, A.; Baykan, B.; Zenclussen, A.C.; Michalsky, E.; Jaeger, I.S.; et al. Survivin minigene DNA vaccination is effective against Neuroblastoma. Int. J. Cancer 2009, 125, 104-114. [CrossRef]

39. Huebener, N.; Fest, S.; Hilt, K.; Schramm, A.; Eggert, A.; Durmus, T.; Woehler, A.; Stermann, A.; Bleeke, M.; Baykan, B.; et al. Xenogeneic immunisation with human tyrosine hydroxylase DNA vaccines suppresses growth of established Neuroblastoma. Mol. Cancer Ther. 2009, 8, 2392-2401. [CrossRef]

40. Gil, M.; Bieniasz, M.; Wierzbicki, A.; Bambach, B.J.; Rokita, H.; Kozbor, D. Targeting a mimotope vaccine to activating Fcgamma receptors empowers dendritic cells to prime specific CD8+ T cell responses in tumor-bearing mice. J. Immunol. 2009, 183, 6808-6818. [CrossRef]

41. Cheung, I.Y.; Cheung, N.-K.V.; Modak, S.; Mauguen, A.; Feng, Y.; Basu, E.; Roberts, S.S.; Ragupathi, G.; Kushner, B.H. Survival Impact of Anti-GD2 Antibody Response in a Phase II Ganglioside Vaccine Trial Among Patients with High-Risk Neuroblastoma with Prior Disease Progression. J. Clin. Oncol. 2021, 39, 215-226. [CrossRef] [PubMed]

42. Vollmer, J.; Krieg, A.M. Immunotherapeutic applications of CpG oligodeoxynucleotide TLR9 agonists. Adv. Drug Deliv. Rev. 2009, 61, 195-204. [CrossRef] [PubMed]

43. Brignole, C.; Pastorino, F.; Marimpietri, D.; Pagnan, G.; Pistorio, A.; Allen, T.M.; Pistoia, V.; Ponzoni, M. Immune cell-mediated antitumor activities of GD2-targeted liposomal c-myb antisense oligonucleotides containing CpG motifs. J. Natl. Cancer Inst. 2004, 96, 1171-1180. [CrossRef] [PubMed]

44. Brignole, C.; Marimpietri, D.; Pastorino, F.; Di Paolo, D.; Pagnan, G.; Loi, M.; Piccardi, F.; Cilli, M.; Tradori-Cappai, A.; Arrigoni, G.; et al. Anti-IL-10R antibody improves the therapeutic efficacy of targeted liposomal oligonucleotides. J. Control. Release 2009, 138, 122-127. [CrossRef]

45. Zhao, Q.; Liu, Y.; Zhang, Y.; Meng, L.; Wei, J.; Wang, B.; Wang, H.; Xin, Y.; Dong, L.; Jiang, X. Role and toxicity of radiation therapy in neuroblastoma patients: A literature review. Crit. Rev. Oncol. Hematol. 2020, 149, 102924. [CrossRef]

46. Hill-Kayser, C.E.; Tochner, Z.; Li, Y.; Kurtz, G.; Lustig, R.A.; James, P.; Balamuth, N.; Womer, R.; Mattei, P.; Grupp, S.; et al. Outcomes After Proton Therapy for Treatment of Pediatric High-Risk Neuroblastoma. Int. J. Radiat. Oncol. Biol. Phys. 2019, 104, 401-408. [CrossRef]

47. Bagley, A.F.; Grosshans, D.R.; Philip, N.V.; Foster, J.; McAleer, M.F.; McGovern, S.L.; Lassen-Ramshad, Y.; Mahajan, A.; Paulino, A.C. Efficacy of proton therapy in children with high-risk and locally recurrent neuroblastoma. Pediatr. Blood Cancer $2019,66$. [CrossRef] [PubMed]

48. Jazmati, D.; Butzer, S.; Hero, B.; Ahmad Khalil, D.; Merta, J.; Baumer, C.; Plum, G.; Fuchs, J.; Koerber, F.; Steinmeier, T.; et al. Proton Beam Therapy for Children with Neuroblastoma: Experiences From the Prospective KiProReg Registry. Front. Oncol. 2021, 10, 617506. [CrossRef] 
49. Nouso, H.; Tazawa, H.; Tanimoto, T.; Tani, M.; Oyama, T.; Sato, H.; Noma, K.; Kagawa, S.; Kobayashi, H.; Noda, T.; et al. Abstract 3831: Development of near-infrared photoimmunotherapy targeting GD2-positive Neuroblastoma. Cancer Res. 2018, 3831. [CrossRef]

50. Maruoka, Y.; Furusawa, A.; Okada, R.; Inagaki, F.; Wakiyama, H.; Kato, T.; Nagaya, T.; Choyke, P.L.; Kobayashi, H. Interleukin-15 after Near-Infrared Photoimmunotherapy (NIR-PIT) Enhances T Cell Response against Syngeneic Mouse Tumors. Cancers 2020, 12, 2575. [CrossRef]

51. Gaze, M.N.; Gains, J.E.; Walker, C.; Bomanji, J.B. Optimisation of molecular radiotherapy with [131I]-meta Iodobenzylguanidine for high-risk Neuroblastoma. Q. J. Nucl. Med. Mol. Imaging 2013, 57, 66-78.

52. Wilson, J.S.; Gains, J.E.; Moroz, V.; Wheatley, K.; Gaze, M.N. A systematic review of 131I-meta iodobenzylguanidine molecular radiotherapy for Neuroblastoma. Eur. J. Cancer 2014, 50, 801-815. [CrossRef] [PubMed]

53. Corroyer-Dulmont, A.; Falzone, N.; Kersemans, V.; Thompson, J.; Allen, D.P.; Able, S.; Kartsonaki, C.; Malcolm, J.; Kinchesh, P.; Hill, M.A.; et al. Improved outcome of 131 I-mIBG treatment through combination with external beam radiotherapy in the SK-N-SH mouse model of Neuroblastoma. Radiother. Oncol. 2017, 124, 488-495. [CrossRef] [PubMed]

54. Yang, X.; Chen, J.; Wang, N.; Liu, Z.; Li, F.; Zhou, J.; Boyuan, T. Impact of extent of resection on survival in high-risk Neuroblastoma: A systematic review and meta-analysis. J. Pediatr. Surg. 2019, 54, 1487-1494. [CrossRef]

55. Holmes, K.; Pötschger, U.; Pearson, A.D.J.; Sarnacki, S.; Cecchetto, G.; Gomez-Chacon, J.; Squire, R.; Freud, E.; Bysiek, A.; Matthyssens, L.F.; et al. Influence of Surgical Excision on the Survival of Patients with Stage 4 High-Risk Neuroblastoma: A Report From the HR-NBL1/SIOPEN Study. J. Clin. Oncol. 2020, 38, 2902-2915. [CrossRef]

56. Wellens, L.M.; Deken, M.M.; Sier, C.F.M.; Johnson, H.R.; De La Jara Ortiz, F.; Bhairosingh, S.S.; Houvast, R.D.; Kholosy, W.M.; Baart, V.M.; Pieters, A.M.M.J.; et al. Anti-GD2-IRDye800CW as a targeted probe for fluorescence-guided surgery in Neuroblastoma. Sci. Rep. 2020, 10, 17667. [CrossRef] [PubMed]

57. Jin, Y.; Li, Y.; Yang, X.; Tian, J. Neuroblastoma-targeting triangular gadolinium oxide nanoplates for precise excision of cancer. Acta Biomater. 2019, 87, 223-234. [CrossRef]

58. Chen, Q.; Ci, T.; Gu, Z. Sprayable gel for postsurgical immunotherapy. Immuno-Oncol. Technol. 2019, 2, 11-13. [CrossRef]

59. Viale, M.; Vecchio, G.; Maric, I.; Cilli, M.; Aprile, A.; Ponzoni, M.; Fontana, V.; Priori, E.C.; Bertone, V.; Rocco, M. Fibrin gels entrapment of a doxorubicin-containing targeted polycyclodextrin: Evaluation of in vivo antitumor activity in orthotopic models of human Neuroblastoma. Toxicol. Appl. Pharmacol. 2019, 385, 114811. [CrossRef]

60. Viale, M.; Bertone, V.; Maric, I.; Cilli, M.; Emionite, L.; Bocchini, V.; Ponzoni, M.; Fontana, V.; De Luca, F.; Rocco, M. Enhanced therapeutic index of liposomal doxorubicin Myocet locally delivered by fibrin gels in immunodeficient mice bearing human Neuroblastoma. Pharmacol. Res. 2020, 105294. [CrossRef] 